Acta Poloniae Historica

108, 2013

PL ISSN 0001-6892

Piotr Guzowski

\title{
THE ORIGINS OF THE EUROPEAN MARRIAGE PATTERN \\ IN EARLY MODERN PERIOD FROM THE PERSPECTIVE OF POLISH HISTORY*
}

\author{
I \\ INTRODUCTION
}

The publication of John Hajnal's seminal articles on the 'European marriage pattern'1 has brought marriage patterns to the centre of scholarly interest not only among demographers, but also among scholars whose main areas of study are economic, legal, and cultural history. ${ }^{2}$ All the scholars, including Hajnal himself, have usually concentrated on determining distinctive features of the pattern, its geographical reach, and various consequences of its existence. Yet, the very origins and circumstances in which the pattern emerged has not been for many years the subject of separate studies. In recent years, however, two very interesting theories have been formulated concerning the time and causes of the emergence of the European marriage pattern and the circumstances of appearance of a distinguishable way of household formation in Western and Central Europe.

* The article was originally published in Polish in Przesztość Demograficzna Polski, 31 (2012), 7-41.

${ }^{1}$ John Hajnal, 'European Marriage Patterns in Perspective', in David V. Glass and David E.C. Eversley (eds.), Population in History: Essays in Historical Demography (London and Chicago, 1965), 101-43; idem, 'Two Kinds of Preindustrial Household Formation System', in Richard Wall, Jean Robin, and Peter Laslett (eds.), Family Forms in Historic Europe (Cambridge, 1983), 65-104.

${ }^{2}$ For a summary of the discussions in historiography, see Mary S. Hartman, The Household and the Making of History: A Subversive View of the Western Past (Cambridge, 2004); Theo Engelen and Arthur P. Wolf (eds.), Marriage and the Family in Eurasia: Perspectives on the Hajnal Hypothesis (Amsterdam, 2005). 
One of these theories was developed by Dutch economic historians Jan Luiten van Zanden and Tine De Moor, ${ }^{3}$ and the other by Michael Mitterauer, an eminent Austrian social historian. ${ }^{4}$ The aim of this article is to look at these theories from the perspective of socioeconomic changes occurring in the Polish lands in the Late Middle Ages and early modern period, described in Polish historiography with which the said authors are not familiar. As it was recently stated by Mikołaj Szołtysek, widespread popularity of the stereotypical view of the European family, rooted in nineteenth-century publications of Frédéric Le Play, ${ }^{5}$ or in an even earlier 'invention' of Eastern Europe by the Enlightenment, ${ }^{6}$ results from three factors. Firstly, Western historians are not familiar with the achievements of contemporary East and Central European historiography (the majority of texts published in native languages). ${ }^{7}$ Secondly, Western scholars tend to draw very far-reaching conclusions from extremely limited data available to them. Finally, a common practice among some Western historians is that they ignore sources which disprove their working assumptions. ${ }^{8}$

${ }^{3}$ Tine De Moor and Jan Luiten van Zanden, 'Girl Power: The European Marriage Pattern and Labour Markets in the North Sea Region in the Late Medieval and Early Modern Period', The Economic History Review, 1xiii, 1 (2010), 1-33.

${ }^{4}$ Michael Mitterauer, Warum Europa? Mittelalterliche Grundlagen eines Sonderwegs (Munich, 2003). I have used the English translation, idem, Why Europe? The Medieval Origins of its Special Path, trans. Gerald Chapple (Chicago and London, 2010); see also his previous papers: 'Medieval Roots of European Family Development', in Jan Michálek (ed.), Stredoeurópske kontexty ludovej kultury na Slovensku (Bratislava, 1995), 95-105, and 'Ostkolonisation und Familienverfassung. Zur Diskussion um die Hajnal-Linie', in Viricene Rajšp and Ernst Bruckmüller (eds.), Vilfanov zbornik. Pravo - zgodovina - narod (Lubljana, 1999), 203-22.

${ }^{5}$ Frédéric Le Play, L'organisation de la famille selon le vrai modèle signalé par l'histoire de toutes les races et de tous les temps (Tours, 1871); Philippe Périer, 'Le Play and his Followers: Over a Century of Achievement', International Social Science Journal, 50 (2002), 343-8.

${ }^{6}$ Larry Wolff, Inventing Eastern Europe: The Map of Civilisation on the Mind of the Enlightenment (Stanford, 1994); Mikołaj Szołtysek and Barbara Zuber-Goldstein, 'Historical Family Systems and the Great European Divide: The Invention of the Slavic East', Demográfia: English Edition, 52 (2009), 5-47.

${ }^{7}$ Studies by Polish scholars: Cezary Kuklo, Michał Kopczyński, and Mikołaj Szołtysek have given answers to many questions, but neither Michael Mitterauer nor Tine De Moor and Jan Luiten van Zanden made any references to them.

${ }^{8}$ Mikołaj Szołtysek, 'Spatial Construction of European Family and Household Systems: A Promising Path or a Blind Alley? An Eastern European Perspective', Continuity and Change, 27 (2012), 12. 
On the other hand, it must be admitted that Polish academics are often unfamiliar with questions posed by their West-European and American colleagues and remain uninformed about their conceptions explaining demographic phenomena of the past. Thus, any form of participation in international debates on European history is an opportunity for Polish historians to take a critical view of their own findings. It can also facilitate the identification of new directions in Polish historical and demographic studies that heretofore have been neglected.

In his first article, John Hajnal divided Europe along the Saint Petersburg - Trieste line into two parts with two different dominant models of marriage. Around the year 1900, in Western Europe, the age at first marriage was relatively late and the number of people who never married was relatively big, whereas in Eastern Europe the situation was exactly opposite. ${ }^{9}$ In another text, he emphasised the relationship between the European marriage pattern and household formation system. Hajnal's argument is that in the North Western Europe, i.e. in Britain, the Netherlands, northern France, German-speaking countries and Scandinavia (except Finland), ${ }^{10}$ the average age at first marriage was more than 23 for women, and over 26 for men. With the moment of marriage a new couple formed a separate household, thus simple households tended to dominate in the North Western Europe. Another characteristic feature of this area was popularity of household service, as a result of which servanthood became an important element in the life cycle of almost all young people (prior to marriage). ${ }^{11}$ European, or rather West-European, model was to dominate in preindustrial societies in the seventeenth and eighteenth centuries. Evidence to support this thesis was provided by historical demographers gathering data from early modern England and Denmark. Other regions of Europe (as it was proven by historical evidence from Russia, Hungary, and Italy) and Asia were characterised, according to Hajnal, by younger age at first marriage (under 21 for women, under 26 for men) and by complex households, where young spouses lived under the same roof with their parents or another closely related couple (sometimes even more than one). ${ }^{12}$

\footnotetext{
${ }^{9}$ Hajnal, 'European Marriage Patterns', 101.

${ }^{10}$ Idem, 'Two Kinds of Preindustrial Household', 66.

${ }^{11}$ Ibidem, 69.

12 Ibidem.
} 
Hajnal did not ask further questions about the time and reasons for emergence of the European marriage pattern. His models have been popularly accepted within the field of historical demography, even though other scholars challenged their claims by noticing flexible boundaries between different regions with particular marriage and household patterns, by pointing out to considerable geographical diversity of marriage and household patterns within some areas of Western Europe itself, and by drawing attention to varying intensity of occurrence of individual marriage and household patterns across Hajnal's regions. ${ }^{13}$ Revisionist approach was also proposed in publications by scholars from Eastern and Central Europe and the Balkans. They tend to emphasise great diversity of family forms in these parts of Europe, as a result of which they often escape simple models of classification. ${ }^{14}$

\section{EUROPEAN VS. POLISH FAMILY PATTERNS}

Having acknowledged all the reservations concerning the precision of Hajnal's line and having recognised the necessity of caution in applying his theory, it must still be admitted that Hajnal's model remains an important element in reconstructing the history of European family. ${ }^{15}$ The point that appears most interesting from the perspective of Polish historical demographers is that Hajnal's line dividing Europe into two parts ran right across the Crown of the Kingdom of Poland, which obviously provokes questions about the predominant marriage pattern

13 Pierre Goubert, 'Family and Province: A Contribution to the Knowledge of Family Structures in Early Modern France', Journal of Family History, 2 (1977), 179-95.

${ }^{14}$ Markus Cerman, 'Central Europe and the European Marriage Pattern: Marriage Patterns and Family Structure in Central Europe, 16th-19th Centuries', in Richard Wall et al. (eds.), Family History Revisited: Comparative Perspectives (Newark, 2001), 282-307; Maria Todorova, Balkan Family Structure and the European Pattern: Demographic Developments in Ottoman Bulgaria (Washington, 2006); Silvia Sovic, "Moving Beyond Stereotypes of "East" and "West", Cultural and Social History, 5 (2008), 141-63; Andrejs Plakans and Charles Whetterell, 'The Hajnal Line and the Eastern Europe', in Engelen and Wolf (eds.), Marriage and the Family, 105-26; Mikołaj Szołtysek, 'Rethinking Eastern Europe: Household-formation Patterns in the Polish-Lithuanian Commonwealth and European Family Systems', Continuity and Change, 23 (2008), 389-427.

${ }^{15}$ Massimo Livi Bacci, The Population of Europe: A History (Oxford, 1999), 107. 
in the Polish lands and about legitimacy of Hajnal's classification of Polish lands as belonging to the Eastern model. ${ }^{16}$

Studies conducted by Polish scholars demonstrate clearly that in the second half of the eighteenth century, in most lands belonging to the Polish-Lithuanian Commonwealth (and in those inhabited in part by Polish people, e.g. Silesia), simple households (3a-3d in Hammel-Laslett classification) were definitely predominant. In towns they were between 66 and 85 per cent of all households (Table 1), ${ }^{17}$ whereas in the countryside their proportion ranged between 70 and 82 per cent (Table 2 ). ${ }^{18}$

TABLE 1. Simple households in selected Polish towns at the end of eighteenth century

\begin{tabular}{llcc}
\hline Town & Year & $\begin{array}{c}\text { Number } \\
\text { of households }\end{array}$ & $\begin{array}{c}\text { Percentage } \\
\text { of simple } \\
\text { households }\end{array}$ \\
\hline Praszka & 1791 & 161 & 85.1 \\
\hline Wieluń & 1791 & 261 & 71.6 \\
\hline Radziejów & 1782 & 124 & 79.1 \\
\hline Olkusz & 1791 & 126 & 79.4 \\
\hline Cracow & 1791 & 1,159 & 67 \\
\hline Warsaw & 1791 & 4,122 & 66.3 \\
\hline
\end{tabular}

Source: Cezary Kuklo, Kobieta samotna w spoteczeństwie miejskim u schytku Rzeczypospolitej szlacheckiej (Białystok, 1998), 77-82.

${ }^{16}$ Although it is not clear whether Hajnal's model was supposed to embrace rural areas only or it included urban centers as well, Tine De Moor and Jan Luiten van Zanden refer to it when they write about both. For this reason, Polish data presented in this article come from both villages and towns.

${ }^{17}$ Cezary Kuklo, Kobieta samotna $w$ spoteczeństwie miejskim u schytku Rzeczypospolitej szlacheckiej (Białystok, 1998), 72-85. Anna Laszuk, Ludność województwa podlaskiego $w$ drugiej potowie XVII wieku (Warsaw, 1999), 194, basing on data from 28 towns of the Podlasie Voivodeship, has shown that in the years 1662-74, 71.3\% of 1,118 households were simple households.

${ }^{18}$ Michał Kopczyński, Studia nad rodzina chtopska w Koronie w XVII-XVIII wieku (Warsaw, 1998), 56, 101; Mikołaj Szołtysek, 'Różnorodność czy tożsamość? Chłopskie gospodarstwo domowe na ziemiach Rzeczypospolitej i Śląska pod koniec XVIII wieku', in Cezary Kuklo (ed.), Rodzina i gospodarstwo domowe na ziemiach polskich w XV-XX wieku (Warsaw, 2008), 375; Mikołaj Szołtysek, 'Three Kinds of Preindustrial Household Formation System in Historical Eastern Europe: A Challenge to Spatial Patterns of the European Family', The History of the Family, 13 (2008), 223-57; idem, 
TABLE 2. Simple households in villages of Polish-Lithuanian Commonwealth and Silesia in the second half of eighteenth century

\begin{tabular}{lc}
\hline \multicolumn{1}{c}{ Region } & $\begin{array}{c}\text { Percentage } \\
\text { of simple } \\
\text { households }\end{array}$ \\
\hline Kuyavia $^{\mathrm{a}}$ & 82.3 \\
\hline $\begin{array}{l}\text { Western lands of Kingdom of Poland and Silesia (Pomerania } \\
\text { Voivodeship, western Greater Poland and Lesser Poland, }\end{array}$ & 77.7 \\
$\begin{array}{l}\text { Silesia) } \\
\text { Red Ruthenia }\end{array}$ & 59.5 \\
\hline $\begin{array}{l}\text { Belarussian lands of Grand Duchy of Lithuania (Minsk, } \\
\text { Nowogródek, Brest voivodeships) }\end{array}$ & 49.7 \\
\hline
\end{tabular}

Source: Mikołaj Szołtysek, 'Life-Cycle Service and Family Systems in the Rural Countryside: A Lesson from Historical East-Central Europe', Annales de démographie historique, 117 (2009), 60.

a 1,901 rural households.

${ }^{\mathrm{b}}$ Total number of rural households in three distinguished parts of Commonwealth and Silesia: 18,440 .

In addition to the Table 2 data, it is worth to mention that the results of analyses based on the seventeenth-century source material (year 1662) from two voivodeships do not differ significantly from those of the second half of the eighteenth century (in Pomerania Voivodeship, $84.8 \%$ of 2,767 households were simple households; in Podlasie Voivodeship $-70.5 \%$ of 4,313 ). Comparison of Polish data and the data collected by the Cambridge Group studying model English parishes, where the percentage of simple households was slightly over 70 per cent, ${ }^{19}$ does not show any striking differences between North-Western Europe and the Crown of the Kingdom of Poland. Such a conclusion, however, can only be accepted with some reservations. First, it cannot be ignored that the structure of households was not uniform across the Polish-Lithuanian Commonwealth and that there was great regional diversity in this respect. For example, the percentage of simple households in Red Ruthenia was significantly smaller than in central or western Poland, while in Belarussian lands of the Grand Duchy of Lithuania it did not even reach 50 per cent

'Life-Cycle Service and Family Systems in the Rural Countryside: A Lesson from Historical East-Central Europe', Annales de démographie historique, 117 (2009), 60.

${ }_{19}$ Peter Laslett, Family Life and Illicit Love in Earlier Generations: Essays in Historical Sociology (Cambridge, 1977), 22. 
(see Table 2). ${ }^{20}$ Second, comparisons of Polish and West-European data are prone to distortions caused by a poorer quality of Polish sources (e.g. less precise in recording kinship) and lack of agreement among Polish historians about the classification of lodgers, which inevitably affects the calculations of the proportion of simple households. ${ }^{21}$ Third, as it was noted by J. Hajnal, in North-Western European system of simple households there was an important link between the moment of concluding marriage and the establishment of an independent household (the relationship is visible when the age at marriage and the age at becoming the head of a household are compared). In Poland, the link between these two events was sometimes rather weak, as shown by Michał Kopczyński and Mikołaj Szołtysek. ${ }^{22}$ It appears that households in Polish lands possessed features of Western as well as Eastern models, and therefore they seem to fit Peter Laslett's fourfold classification of the geography of family forms (Central European type) much more than the simple, twofold classification of J. Hajnal.

\section{III}

\section{AGE AT FIRST MARRIAGE AND PROPORTION} OF UNMARRIED WOMEN

Equally complex in assessment is the problem of the age at marriage. On the one hand, in the second half of eighteenth century men's age at first marriage, both in the countryside (Table 3 ) and in Polish and Silesian towns (Table 4) was 26 and more, which met the criteria of the 'European marriage pattern'. For the earlier centuries the fragmentary data at our disposal are similar: for Gdańsk fifteenthand sixteenth-century elites, it was 30; in Torun (1636-1700), the figure was 28.4.

On the other hand, women in Silesia married at the age of 21.5 to 25 , and in some areas in the Crown women's age at first marriage was

${ }^{20}$ Szołtysek, 'Life-Cycle Service', 60.

${ }^{21}$ E.g. Michał Kopczyński includes lodgers as members of rural households and consequently prefers the term houseful to household; Cezary Kuklo in his description of urban households claims that there are no grounds for including lodgers.

${ }^{22}$ Kopczyński, Studia nad rodzina, 144; Mikołaj Szołtysek, 'Dziedziczenie i międzypokoleniowa wymiana w parafii Bujaków 1766-1803, głos w dyskusji nad geografią europejskich form rodzinnych', Przeszłość Demograficzna Polski, 26 (2005), 30. 
19 to 23 . The conclusion is that the difference in the age of marriage between men and women was bigger than in Western Europe, so Polish lands did not fit the model created by Hajnal.

TABLE 3. Age at first marriage in villages belonging to urban parishes in the Crown of the Kingdom of Poland and Silesia

\begin{tabular}{|c|c|c|c|c|}
\hline \multirow[t]{2}{*}{ Parish } & \multirow[t]{2}{*}{ Region } & \multirow[t]{2}{*}{ Period } & \multicolumn{2}{|c|}{$\begin{array}{c}\text { Age at first } \\
\text { marriage (mean) }\end{array}$} \\
\hline & & & Men & Women \\
\hline Szaradowo & Greater Poland & $1731-1800$ & 27.4 & 21.9 \\
\hline Wieleń & Greater Poland & $\begin{array}{l}\text { 2nd half } \\
\text { of } 18 \text { th } \mathrm{c} .\end{array}$ & 28.2 & 22.3 \\
\hline Ostrów Mazowiecka & Masovia & 18th c. & 27.9 & 23.8 \\
\hline Bejsce & Lesser Poland & $1781-1800$ & 26.6 & 20.5 \\
\hline $\begin{array}{l}\text { Brzeżany (Berezhani) } \\
\text { (Roman Catholics) }\end{array}$ & Red Ruthenia & $1784-1800$ & 24.8 & 19 \\
\hline $\begin{array}{l}\text { Brzeżany (Berezhani) } \\
\text { (Greek Catholics) }\end{array}$ & Red Ruthenia & $1784-1800$ & 24.1 & 19 \\
\hline Krappitz (Krapkowice) & Silesia & $1761-1800$ & 25 & 22 \\
\hline Tost (Toszek) & Silesia & $1791-1800$ & 26.1 & 22.5 \\
\hline Langenbielau (Bielawa) & Silesia & $1766-1830$ & 26.7 & 23.5 \\
\hline $\begin{array}{l}\text { Groß Strehlitz (Strzelce } \\
\text { Opolskie) }\end{array}$ & Silesia & $1766-1830$ & $24.6-29.2$ & $21.5-25.1$ \\
\hline Schönwaldau (Rząśnik) & Silesia & $1794-1800$ & 27.4 & 25.4 \\
\hline
\end{tabular}

Source: Cezary Kuklo, Demografia Rzeczypospolitej przedrozbiorowej (Warsaw, 2009), 279.

${ }^{a}$ Age range at marriage in different social groups.

It must be remembered, though, that the picture that results from the analysis of Polish sources is far from homogeneous because among parishes whose archives have been examined by Polish scholars there are also many that ideally meet the criteria of the European marriage pattern. ${ }^{23}$ Moreover, some changes occurring over time are clearly visible in the sources. In Torun, the age at which women were married increased during the seventeenth century from 19.5 to 24.5 , on

${ }^{23}$ See: Mikołaj Szołtysek, 'Central European Household and Family Systems, and the Hajnal-Mitterauer Line: The Parish of Bujakow (18th-19th centuries)', in The History of the Family, 12 (2007), 23. 
average.$^{24}$ In the seventeenth century, in the Warsaw parish of St John, the average age of women entering marriage was 20.1, and of men, 23.7. ${ }^{25}$ In the second half of the eighteenth century, women in the parish of Holy Cross married at 21.8, while men at $29 .{ }^{26}$ Although the change in the average age of men marrying for the first time is more noticeable, the fact of its occurrence in both sex groups must be recognised.

TABLE 4. Age at first marriage in Polish and Silesian towns in the eighteenth and beginning of the nineteenth century

\begin{tabular}{|c|c|c|c|c|}
\hline \multirow[t]{2}{*}{ Town } & \multirow[t]{2}{*}{ Region } & \multirow[t]{2}{*}{ Period } & \multicolumn{2}{|c|}{$\begin{array}{l}\text { Age at first } \\
\text { marriage }\end{array}$} \\
\hline & & & Men & Women \\
\hline Poznań & Greater Poland & $1800-1815$ & 29 & 24 \\
\hline Warsaw $^{\mathrm{a}}$ & Masovia & $1740-1769$ & 28.8 & 22.2 \\
\hline Warsaw $^{\mathrm{a}}$ & Masovia & $1770-1799$ & 29 & 21.8 \\
\hline Wieleń & Greater Poland & $\begin{array}{l}\text { 2nd half of } \\
\text { 18th c. }\end{array}$ & 29.5 & 24.3 \\
\hline Ostrów Mazowiecka & Masovia & 18th c. & 27 & 23 \\
\hline Krappitz (Krapkowice) & Silesia & $1761-1800$ & 27 & 23 \\
\hline $\begin{array}{l}\text { Groß Strehlitz (Strzelce } \\
\text { Opolskie) }\end{array}$ & Silesia & $1761-1800$ & $22.8-35.5$ & $20-25.5$ \\
\hline Tost (Toszek) & Silesia & $1791-1800$ & 24.4 & 22.3 \\
\hline $\begin{array}{l}\text { Brzeżany (Berezhani) } \\
\text { (Roman Catholics) }\end{array}$ & Red Ruthenia & $1784-1800$ & 26 & 20.9 \\
\hline
\end{tabular}

Source: Kuklo, Demografia, 279.

${ }^{a}$ Holy Cross Parish.

${ }^{\mathrm{b}}$ Age range at marriage in different social groups.

No less problematic is the question of the percentage of women living in definitive celibacy. Since it is difficult to identify people's definitive celibacy in past societies, historical demographers attempt alternatively to juxtapose the proportions of married and unmarried women

${ }^{24}$ Krzysztof Mikulski, 'Regres demograficzny w Toruniu w XVII wieku w świetle analizy małżeństw luteranów', in Przełomy w historii. XVI Powszechny Zjazd Historyków Polskich. Wroctaw 15-18 września 1999 roku. Pamiętniki, iii, pt. 1 (Torun, 2001), 312.

${ }^{25}$ Maria Sierocka-Pośpiech, 'Rynek małżeński w Starej Warszawie w XVII wieku na podstawie rejestracji ślubów parafii św. Jana', in Andrzej Karpiński et al. (eds.), Społeczeństwo a rodzina (Społeczeństwo Staropolskie, N. Ser., iii, Warsaw, 2011), 216.

${ }^{26}$ Cezary Kuklo, Rodzina w osiemnastowiecznej Warszawie (Białystok, 1991), 175. 
(widows and young maids). Hajnal claimed that late marriages in North-Western Europe (especially in the case of women) contributed to an increase in the proportion of unmarried women, who made at least 10 per cent and usually more than 15 per cent among women about the age of 50. In female adult population (aged 20 and over) young maids and widows were about 40 per cent of the total. ${ }^{27}$ Their growing number had a greater effect on the fertility level than the practice of postponing marriage. ${ }^{28}$

The issue of definitive celibacy has not been widely studied in Polish historiography, but some conclusions can be presented, for instance, for the largest Polish city at the end of the eighteenth century. It is estimated that about 10 to 12 per cent of women in Warsaw at that time never married. ${ }^{29}$ In the countryside, the percentage was somewhat smaller, but it also reached about 10 per cent. ${ }^{30}$ Unmarried women over the age of 20 (incl. widows) made about 20 to 40 per cent of all women inhabiting small towns, whereas in bigger cities, such as Cracow or Warsaw, they were over 40 per cent of the total adult female population (over 20) ${ }^{31}$ It must be remembered that data from the end of the eighteenth century do not necessarily reflect the reality in the previous centuries. As Jacek Wiesiołowski writing about the Polish countryside culture remarked:

It is characteristic that the Polish language did not have a word for unmarried adults. In mid-sixteenth century the authors of Latin-Polish dictionaries found it difficult to translate the word coelebs. Jan Cervus of Tuchola rendered it as bezżenia, nieżonaty, niemężatka [Eng. not married, without a wife, without a husband], with characteristic negative prefixes (bez-, nie-) used to express inappropriateness of the very notion in the Polish language. In rural contexts, the experience of social life showed that an unmarried person could not be the head of a household without violating the norms of social coexistence. ${ }^{32}$

${ }^{27}$ Hajnal, 'European marriage patterns', 102, 117, 136.

${ }^{28}$ David R. Weir, 'Rather Never Than Late: Celibacy and the Age at Marriage in English Cohort Fertility, 1441-1871', Journal of Family History, 9 (1984), 340-54; Roger Schofield, 'English Marriage Patterns Revisited', Journal of Family History, 10 (1985), 2-10.

${ }^{29}$ Kuklo, Rodzina w osiemnastowiecznej Warszawie, 172.

${ }^{30}$ Idem, Demografia Rzeczypospolitej przedrozbiorowej (Warsaw, 2009), 277.

${ }^{31}$ Idem, Kobieta samotna, 59.

32 Jacek Wiesiołowski, 'Kultura i obyczaje kręgu wiejskiego', in Bronisław Geremek (ed.), Kultura Polski średniowiecznej XIV-XV w. (Warsaw, 1997), 138. 
The final element of difference between Polish preindustrial society and the model of family and household created by Hajnal is the importance of domestic service and servants. Polish studies into this issue cannot be compared in terms of extent with research conducted by Western scholars, and sometimes their findings do not fit exactly the models propounded by Western historiography. Nevertheless, publications of Anna Kamler (maiden name: Izydorczyk) provided clear evidence that household service was a common phenomenon in the early modern Poland (in the 16th and 17th centuries). ${ }^{33}$ Its role in rural context was, however, regionally diversified (Table 5). Mikołaj Szoltysek found that in Silesia, western Lesser Poland, Greater Poland, and Pomerania almost 40 per cent of peasant households employed domestic servants, who made 13.5 per cent of village population. ${ }^{34}$ In Kuyavia, servants in gentry and peasant households accounted for 24.4 per cent of village population ${ }^{35}$ (in peasant households $-14.8 \%$ ), ${ }^{36}$ while in villages on Polish-Ruthenian border, servants made between 12 and 21 per cent of inhabitants. ${ }^{37}$ The role of domestic service in household structure in the lands inhabited by Ruthenians was minimal..$^{38}$ It is estimated that the percentage of servants in the total population of medium and big Polish towns was about 20 to 33 per cent in the eighteenth century, ${ }^{39}$ whereas in small towns, which were the most numerous in Poland, the percentage of servants was lower. ${ }^{40}$ The importance of service in the majority of rural areas of the Crown of the Kingdom of Poland and Silesia was not lesser than in model English parishes, where the percentage of servants was 11.5 to 15.5 per cent of total population and the percentage of households employing servants ranged between 24 and 33 per cent. ${ }^{41}$

${ }^{33}$ Anna Kamler, Chtopi jako pracownicy najemni na wsi matopolskiej $w$ XVI $i$ w pierwszej potowie XVII wieku (Warsaw, 2005).

34 Szołtysek, 'Life-Cycle Service', 60.

${ }^{35}$ Kopczyński, Studia nad rodzina, 121.

${ }^{36}$ Ibidem.

${ }^{37}$ Zdzisław Budzyński and Małgorzata Sochacka, 'Ludność parafii Hyżne koło Rzeszowa w świetle spisów spowiedniczych z lat 1728-1747’, in Zdzisław Budzyński (ed.), Studia i materiaty z dziejów spotecznych Polski południowo-wschodniej, vol. 1 (Rzeszów, 2003), 179.

38 Szołtysek, 'Life-Cycle Service', 60.

${ }^{39}$ Kuklo, Demografia, 367.

${ }^{40}$ Radosław Poniat, Stużba domowa $w$ miastach na ziemiach polskich od połowy XVIII do końca XIX wieku (unpublished Ph.D. thesis, Białystok, 2012), 151.

${ }^{41}$ Laslett, Family Life, 30. 
TABLE 5. Domestic servants in the countryside of Polish-Lithuanian Commonwealth and Silesia

\begin{tabular}{|c|c|c|c|}
\hline Region & Period & $\begin{array}{l}\text { Percentage of } \\
\text { servants in } \\
\text { the population }\end{array}$ & $\begin{array}{l}\text { Percentage of } \\
\text { households } \\
\text { employing } \\
\text { servants }\end{array}$ \\
\hline Lesser Poland & 1590 & 16.3 & \\
\hline Masovia & 1590 & 11.4 & \\
\hline Pomerania Voivodeship & 1662 & $19-21$ & 41 \\
\hline $\begin{array}{l}\text { Western Greater Poland, Western } \\
\text { Lesser Poland, Silesia }\end{array}$ & $\begin{array}{l}\text { 2nd half of } \\
18 \text { th c. }\end{array}$ & 13.3 & 39.4 \\
\hline Kuyavia & $\begin{array}{l}\text { 2nd half of } \\
18 \text { th c. }\end{array}$ & 24.4 & \\
\hline $\begin{array}{l}\text { Red Ruthenia (Chełm Land and } \\
\text { district of Tarnopol) }\end{array}$ & $\begin{array}{l}\text { 2nd half of } \\
18 \text { th c. }\end{array}$ & 2.8 & 12.2 \\
\hline $\begin{array}{l}\text { Polish-Ruthenian borderland } \\
\text { (Przemyśl Land) }\end{array}$ & $\begin{array}{l}\text { 2nd half of } \\
\text { 18th c. }\end{array}$ & $12-21^{a}$ & \\
\hline $\begin{array}{l}\text { Grand Duchy of Lithuania (Vilna } \\
\text { and Minsk voivodeships) }\end{array}$ & $\begin{array}{l}\text { 2nd half of } \\
18 \text { th c. }\end{array}$ & 0.1 & 2.1 \\
\hline $\begin{array}{l}\text { Łowicz Duchy of the Archbishop } \\
\text { of Gniezno (Masovia) }\end{array}$ & $\begin{array}{l}\text { 2nd half of } \\
18 \text { th c. }\end{array}$ & & 26.9 \\
\hline $\begin{array}{l}\text { Parish of Pępowo (Greater Po- } \\
\text { land) }\end{array}$ & 1777 & 18 & \\
\hline $\begin{array}{l}\text { Crown estates in Sandomierz } \\
\text { Voivodeship (Lesser Poland) }\end{array}$ & 1789 & & 40 \\
\hline Wieluń Land & 1791 & 12.5 & \\
\hline $\begin{array}{l}\text { Niestronno estate of the Arch- } \\
\text { bishop of Gniezno (Greater Po- } \\
\text { land) }\end{array}$ & 1797 & 14 & 64 \\
\hline
\end{tabular}

Sources: Zdzisław Budzyński and Małgorzata Sochacka, 'Ludność parafii Hyżne koło Rzeszowa w świetle spisów spowiedniczych z lat 1728-1747', in Zdzisław Budzyński (ed.), Studia i materiaty z dziejów spotecznych Polski potudniowo-wschodniej, vol. 1 (Rzeszów, 2003), 179; Marek Górny, Mieszkańcy parafii pępowskiej w 1777 roku. Analiza księgi status animarum (Wrocław, 1994), 18; Michał Kopczyński, Studia nad rodzina chtopska w Koronie w XVII-XVII wieku (Warsaw, 1998), 60-1, 120; Helena Madurowicz and Antoni Podraza, 'Z problematyki rozwarstwienia wsi w Polsce XVIII wieku', Kwartalnik Historyczny, lxi, 1 (1954), 219; Włodzimierz Obraniak, 'Oblicze demograficzne wsi wieluńskiej w epoce Sejmu Wielkiego’, Studia Demograficzne, 16 (1968), 120; Jerzy Senkowski, 'Zachowane rejestry pogłównego 1590 r.', Kwartalnik Historii Kultury Materialnej, xviii, 3 (1970), 403-25; Szołtysek, 'Life-Cycle Service', 60; Jerzy Topolski, Potożenie $i$ walka klasowa chtopów w XVIII w. $w$ dobrach arcybiskupstwa gnieźnieńskiego (Warsaw, 1956), 132-3.

${ }^{a}$ There were considerable differences between individual villages within one parish - Hyżne. 
TABLE 6. Domestic servants in selected Polish towns at the end of the eighteenth century

\begin{tabular}{lcc}
\hline \multicolumn{1}{c}{ Town } & Year & $\begin{array}{c}\text { Percentage of servants } \\
\text { in the population }\end{array}$ \\
\hline Poznań & 1789 & 20.9 \\
\hline Warsaw & 1795 & 17.5 \\
\hline Cracow & 1795 & 27.8 \\
\hline Sandomierz & 1777 & 19.8 \\
\hline Będzin & 1789 & 26.1 \\
\hline Wieluń & 1791 & 16.8 \\
\hline
\end{tabular}

Source: Radosław Poniat, Stużba domowa w miastach na ziemiach polskich od połowy XVIII do końca XIX wieku (unpublished Ph.D. thesis written under the supervision of professor Cezary Kuklo, Białystok, 2012), 151.

To summarise our examination of similarities between marriage, family and household patterns in Poland and Western Europe, it ought to be stated that Polish reality did not correspond with all elements proposed by Hajnal in his East European model. Dominance of simple households and the role of domestic service were similar in Poland and in North-Western Europe. Unlike in North-Western Europe, however, Polish women tended to marry younger and the percentage of unmarried women in population was lower. Polish scholars found out also that in Poland a link between concluding marriage and establishing an independent household was not always obvious.

IV

\section{ORIGINS OF THE EUROPEAN MARRIAGE PATTERN}

Shortage of data for periods prior to the seventeenth century forced Hajnal to focus his interest on the time between the seventeenth and the nineteenth centuries. Meanwhile, many historians have made their attempts at explaining the origins and identifying the exact moment of creation of European marriage and family patterns. Some scholars point to Tacitus for the earliest information about late marriages among Germanic tribes. ${ }^{42}$ It is popularly accepted, though, that both late marriages and dominance of nuclear families became large-scale

42 David Levine, 'Recombinant Family Formation Strategies', Journal of Historical Sociology, 2 (1989), 93. 
phenomena in the Middle Ages. ${ }^{43}$ Beatrice Gotlieb claims that the earliest direct mention of nuclear families is in late thirteenth-century England, but in the following centuries such families became at least 50 per cent of all households in various regions of Western Europe. ${ }^{44}$ Some evidence for late marriages in England prior to the Black Death was found by Richard Smith, ${ }^{45}$ while for the period after the Black Death, by Herbert Enoch Hallam. ${ }^{46}$ Their findings were used by Wally Seccomb, who has proved that the situation in England and on the Continent differed because, although nuclear families were also becoming more common on the continent after the Black Death, the change was much slower than in England.$^{47}$ Examples of differences between late medieval Mediterranean and English models are provided in the analysis of Tuscan family patterns in the fifteenth century. ${ }^{48}$ Popularity of the European marriage pattern and dominance of nuclear families characterised rural as well as some urban communities in Western Europe ${ }^{49}$ The proportion of unmarried women in some towns and cities (e.g. Reims, York) increased. ${ }^{50}$ As shown by

${ }^{43}$ Ibidem, 89-115.

${ }^{44}$ Beatrice Gotlieb, The Family in the Western World from the Black Age to the Industrial Age (Oxford, 1993), 13.

${ }^{45}$ Richard Smith, 'Some Reflections on the Evidence for the Origins of the European Marriage Pattern in England', in Chris Harris (ed.), Sociology of the Family: New Directions for Britain (Sociological Review Monograph, 28, Keele, 1979), 97-101; Richard Smith, 'Hyphothèses sur la nuptialité en Angleterre aux XIIIe-XIVe siècles', Annales. E.S.C., 38 (1983), 120.

${ }^{46}$ Herbert E. Hallam, 'Age at First Marriage and Age of Death in Lincolnshire Fenland, 1252-1478', Population Studies, 39 (1985), 55-69.

${ }^{47}$ Wally Seccombe, A millennium of Family Change: Feudalism to Capitalism in Northwestern Europe (London, 1992), 151; idem, 'The Western European Marriage Pattern in Historical Perspective: A Response to David Levine', Journal of Historical Sociology, 3 (1990), 50-74.

${ }^{48}$ David Herlihy and Christiane Klapisch-Zuber, Tuscans and Their Families: A Study of Florentine Catasto of 1427 (New Haven and London, 1985), 202-7; David Herlihy, Medieval Household (Studies in Cultural History, Cambridge, Mass., 1985), 108-9; about other regions in Europe, see Larry Poos, 'The Pre-History of Demographic Regions in Traditional Europe', Sociologia Ruralis, 26 (1986), 228-48.

${ }^{49}$ Katherine A. Lynch, 'The European Marriage Pattern in the Cities: Variations on a Theme by Hajnal', Journal of Family History, xvi, 1 (1991), 79-96; eadem, Individuals, families, and communities in Europe, 1200-1800: The Urban Foundations of Western Society (Cambridge, 2003), 58-9.

${ }^{50}$ Pierre Desportes, 'La population de Reims au XVe siècle d'après un dénombrement de 1422', Le Moyen Âge, 72 (1966), 487-501; P.J.P. Goldberg, Women, 
Maryanne Kowaleski, in late medieval English, French, German, and Swiss towns unmarried women made over 40 per cent of the adult female population (over 14)..$^{51}$

Following the idea of late medieval origins of the European marriage pattern, two scholars from the University of Utrecht, Tine De Moor and Jan Luiten van Zanden, studying economic, social and cultural causes of this phenomenon, published their findings in The Economic History Review, giving their article a significant title: 'Girl Power: The European Marriage Pattern and Labour Markets in the North Sea Region in the Late Medieval and Early Modern Period'. These two authors' determination to explain the origins of the European marriage pattern derived from their conviction about its decisive influence on the exceptional economic growth of Northern and Western European countries, England and the Netherlands in particular. They believed that the emergence of the European marriage pattern was an institutional response to the growing possibilities on the labour market after the Black Death and it was a deliberate strategy of hired workers, forming about 30 to 60 per cent of the population. ${ }^{52}$ Tine De Moor and Jan Luiten van Zanden identified two constitutive elements of the European marriage pattern which affected the level of fertility. One was the late age at first marriage, the other was a big number of unmarried women. In their article they concentrated on the former. They claimed that postponing the time of first marriage was a combined effect of three socio-economic and ideological factors occurring in North-Western Europe: (i) emphasis put by the Church on consensus of the spouses instead of marriages arranged by parents; (ii) strong position of women in the transference of property between parents and children and husbands and wives; (iii) expansion and greater access to the labour market. ${ }^{53}$ All these factors presented by De Moor and van Zanden as characteristic of the Netherlands and England at the turn of the Middle Ages will

Work, and Life Cycle in a Medieval Economy: Women in York and Yorkshire c. 1300-1520 (Oxford, 1992), 225-32.

${ }^{51}$ Maryanne Kowaleski, 'Singlewomen in Medieval and Early Modern Europe: The demographic Perspective', in Judith Bennett and Amy M. Froide (eds.), Single Women in the European Past, 1250-1800 (Philadelphia, 1999), 41-51, Table A1, p. 326-7.

${ }^{52}$ De Moor and van Zanden, 'Girl power', 1-33.

${ }^{53}$ Ibidem, 3. 
be reconsidered herein to show whether and how they affected also the Polish reality at the end of the Middle Ages and the beginning of the early modern period.

CONSENSUS AS A BASIS FOR THE FORMATION OF MARRIAGE

The mutual consent as a basis for marriage formation in the European marriage pattern is emphasised by Tine De Moor and Jan Luiten van Zanden. They argue that the Christian doctrine of consensual marriage strengthened the position of women because they became in principle 'equal' partners in the contract. A woman had, at least theoretically, an equal right to choose a husband on her own, just as much as a man could select a wife. The two Dutch historians concluded that the doctrine of consensual marriage emphasised the importance of mutual love between partners as a prerequisite for marriage. De Moor and van Zanden quote David Herlihy who wrote that:

The father ... could neither force a son or daughter into an unwanted marriage, nor prevent him or her from marrying. ... The Church's doctrine was a damaging blow to paternal authority within the medieval household, and by itself assured that the medieval family could never develop into a true patriarchy. ${ }^{54}$

It prompted some scholars to conclude that the most characteristic feature of the European marriage pattern was the fact that parents were no longer capable of exercising control over their adult children. ${ }^{55}$ As a result, fathers were more likely to allow their children to leave house and live their lives on their own. At the same time other parents' children were hired as servants to perform tasks in the household that would elsewhere, in China for example, be performed by the father's own children. ${ }^{56}$

It has been noted that although the doctrine of consensual marriage was promoted by Catholic Church across Europe, it was in its north-western part that the European marriage pattern

${ }^{54}$ Herlihy, Medieval Household, 81.

55 Theo Engelen, 'The Hajnal Hypothesis and Transition Theory', in Engelen and Wolf (eds.), Marriage and the Family, 51-73.

56 De Moor and van Zanden, 'Girl Power', 7. 
emerged. ${ }^{57}$ An explanation for this fact has been sought in greater resistance of common people in South and East Europe to the idea of consensual marriage, even against the official teaching of the Church. Although De Moor and van Zanden claim that it was not coincidental that the prevalence of the European marriage pattern coincided with the presence of the Catholic Church, they also admit that Catholicism was definitely not enough for the European marriage pattern to emerge and that some other factors must have also been involved..$^{58}$

It is popularly accepted in Polish historiography that "the institution of family had been fully Christianised by the end of the thirteenth century due to the introduction of the Christian concept of marriage and the popularisation of sacraments", while "the model of indissoluble, equal, monogamous, faithful, fertile marriage" was propagated in hagiographic literature. ${ }^{59}$ The Church hierarchy also put much pressure on popularising Roman and canon law in Poland. ${ }^{60}$ The oldest known codes of canon law in Poland reveal that ideas concerning marriage formation spread from Rome to Poland relatively quickly. Eighteen years before the Fourth Lateran Council introduced a rule that marriage ceremony should be performed in facie ecclesiae, that is by a priest, the very idea was promoted in Poland by the papal legate Pietro Capuano. ${ }^{61}$ Adam Vetulani wrote that "Since the beginning of the thirteenth century Polish clergy kept up with the latest papal directives and codes of canon law and tried to purchase copies for their own use." ${ }^{2}$ Three archbishops of Gniezno issued their own provincial statutes which were to be recognised and enforced in all Polish lands: Jarosław Bogoria Skotnicki in 1357, Mikołaj Trąba in 1420, and Jan Easki in $1523 .{ }^{63}$ All these codes included rules and

57 Hartman, The Household, 98.

58 De Moor and van Zanden, 'Girl Power', 7.

${ }^{59}$ Jan Tyszkiewicz, 'Rodzina w Polsce na początku XIII w.', in Stefan K. Kuczyński (ed.), Społeczeństwo Polski średniowiecznej, vol. 6 (Warsaw, 1994), 119.

${ }^{60}$ Ibidem.

61 'Rocznik kapitulny krakowski', ed. August Bielowski, in Monumenta Poloniae Historica, ii (Lvov, 1872), 800; Władysław Abraham, Zawarcie matżeństwa w pierwotnem prawie Polskiem (Lvov, 1925), 349.

62 Adam Vetulani, $Z$ badań nad kultura prawnicza w Polsce piastowskiej (Wrocław, 1976), 113.

${ }^{63}$ Ignacy Subera, Synody prowincjonalne arcybiskupów gnieźnieńskich (Warsaw, 1971), 73-104; “Debent autem iniri Matrimonia, libero et mutuo contrahentium 
regulations of canon law concerning marriage, and so did legislation passed by diocesan synods. ${ }^{64}$ Beside the emphasis on consent being expressed by a bride and a groom during the marriage ceremony, Church authorities insisted also on introducing ceremonial betrothal witnessed by a priest. The aim of the latter was not only to strengthen the bond between future spouses and make it more difficult for either partner to withdraw from the promise of marriage, but above all to give a woman an opportunity to express her will freely. ${ }^{65}$ Resolutions of provincial and diocesan synods were to be made known to the clergy on the parish level and the procedure was described in the acts of the 1357 provincial synod. ${ }^{66}$ Parish priests were then supposed to propagate the rules in sermons and the work of ministry. ${ }^{67}$

It took some time to enforce canons relating to marriage in Poland, but it is now believed that by the end of the Middle Ages, getting married by moving in together without a formal ceremony performed in the presence of a priest, which had been the most popular way of entering marriage, had become to be viewed as inappropriate. ${ }^{68}$ Gradually, some kind of symbiosis between lay and ecclesiastical forms of marriage formation was established, with local customs being still respected. ${ }^{69}$ In spite of church's and local administration's opposition, marriages by consensual abduction occasionally took place in the late medieval and at the beginning of the early

consensu” - 'Statut Jana Wężyka z 1628 r.', in Ignacy Subera (ed.), Synody prowincjonalne arcybiskupów gnieźnieńskich. Wybór tekstów ze zbioru Jana Wężyka z r. 1731 (Warsaw, 1981), 299.

${ }^{64}$ Statuta synodalia episcoporum Cracoviensium XIV et XV saeculi (hereafter: SSEC), ed. Udalryk Heyzmann (Starodawne Prawa Polskiego Pomniki, iv, Cracow, 1875), 9; similarly: 'The Synod of bishop Wojciech Jastrzębiec, 1423', ibidem, 73; see Adam Krawiec, 'Problematyka małżeńska w średniowiecznym ustawodawstwie synodalnym Kościoła polskiego', in Krzysztof Kaczmarek and Jarosław Nikodem (eds.), Docendo discimus. Studia historyczne ofiarowane Profesorowi Zbigniewowi Wielgoszowi $w$ siedemdziesiąta rocznice urodzin (Poznań, 2000), 247-59; Adam Krawiec, Seksualność w średniowiecznej Polsce (Poznań, 2000), 74.

${ }^{65}$ SSEC, 234-5; Abraham, Zawarcie matżeństwa, 355.

${ }^{66}$ Ignacy Subera, Historia źródet i nauki prawa kanonicznego (2nd edn, Warsaw, 1977), 134.

${ }^{67}$ Wiesiołowski, 'Kultura i obyczaje', 140-1.

${ }^{68}$ Maria Koczerska, 'Zawarcie małżeństwa wśród szlachty w Polsce późnego średniowiecza', Przeglad Historyczny, lxvi, 1 (1975), 6-7; eadem, Rodzina szlachecka w Polsce późnego średniowiecza (Warsaw, 1977), 34-5.

${ }^{69}$ Eadem, 'Zawarcie małżeństwa', 22. 
modern period when elite children wished to get married against their parents' objections. ${ }^{70}$

The canons and decrees of the Council of Trent were acknowledged in Poland initially by the provincial synod in Lvov in 1564 (for the Lvov archbishopric) and then by two provincial synods in Piotrków in 1577 and 1589 (for the archbishopric of Gniezno). The introduction of changes in local church laws and implementing them in the work of ministry and in the lives of people was a long-time process. An event of considerable importance in the process was publication of a pastoral letter by Cracow Bishop Bernard Maciejowski in 1601, which took the form of a manual for parish clergy first in the Cracow diocese and from 1608 in the whole of Poland. ${ }^{71}$ As regards marriage, Maciejowski makes a strong point that "the sacrament of marriage requires free will and consent of both parties". ${ }^{72}$ Feudal lords and royal officials, under whose authority marrying couples remained, were also warned that forcing their subjects into marriage was forbidden under the threat of excommunication. ${ }^{73}$

It is of course difficult to measure the extent to which church regulations were observed in everyday life, especially that they regarded matters where distinguishing between consent under pressure and heartfelt consent was and still is very difficult. Some help in this matter is provided by the records of Polish courts dealing with matrimonial cases. The records reveal that coercion was very rarely a basis for the annulment of marriage. In the fifteenth-century court in Lublin, only 6 per cent of marriages were declared null on this account. ${ }^{74}$ On the other hand, in the early modern period an increasing number of women appearing in court to have their marriages annulled because of the fact that they had been forced by their husbands, parents, relatives or feudal lords to marry may be indicative of women's growing self-awareness. ${ }^{75}$

70 Ibidem, 9-10; Edyta Bezubik, 'Rapt w okresie staropolskim', Studia Podlaskie, ix (1999), 65-6.

${ }^{71}$ Stanisław Litak, Od reformacji do oświecenia. Kościót katolicki w Polsce nowożytnej (Lublin, 1994), 60-1.

72 Sławomir Nasiorowski, List pasterski kardynała Bernarda Maciejowskiego (Lublin, 1990), 235.

${ }^{73}$ Ibidem.

${ }^{74}$ Piotr Hemperek, 'Sprawy małżeńskie w oficjalacie okręgowym w Lublinie w XV w.', Roczniki Teologiczno-Kanoniczne, xvii (1970), 34.

75 Walenty Wójcik, 'Prawo małżeńskie w praktyce oficjalatu okręgowego w Sandomierzu', Roczniki Teologiczno-Kanoniczne, ix (1962), 132-3; Grzegorz Jawor, 'Obraz 
Decline in the number of marriages arranged by parents may also be explained by demographic factors. Using seventeenth- and eighteenth-century data, we may determine the age at first marriage in the lands of the Polish Crown at over 20 for women and over 26 for men. ${ }^{76}$ In the fifteenth and sixteenth centuries, the approximate time of economic activity of Polish peasants, measured from the moment a man established his own household and started a family to his retirement or death, was about twenty years. ${ }^{77}$ Thus, it is very likely that when young people married and created their separate households their parents had already been dead. The situation was very similar among city dwellers. Andrzej Wyczański noted that among members of the guild of goldsmiths in Cracow succession was very often disrupted and only 22 per cent of goldsmiths had been mature enough on their fathers' death to inherit their businesses. ${ }^{78}$ In this respect, Poland was not exceptional in Central Europe. As it was shown by Michael Mitterauer and Reinhard Sieder, among Austrian peasantry, property was passed directly from father to son in only 36 per cent of cases. ${ }^{79}$

It seems that the role of feudal lords in arranging their subjects' marriages was also relatively limited, especially with regard to women. Although peasant women, like their fathers, brothers or husbands, were also somebody's subjects - the king's, the bishop's, the town's or the nobleman's - they were in fact more independent of their lords than men. Fourteenth-century legislation prohibiting peasants

rodziny chłopskiej w Polsce XV wieku w świetle ksiąg oficjała lubelskiego', Annales Universitatis Mariae Curie-Skłodowska. Sectio F, Historia, xli/xlii (1986/7), 89.

${ }^{76}$ Kuklo, Demografia, 279.

${ }^{77}$ Andrzej Wyczański, 'Powrót do dyskusji o łanach pustych', in Piotr Franaszek (ed.), Celem nauki jest człowiek... Studia $z$ historii spotecznej ofiarowane Helenie Madurowicz-Urbańskiej (Cracow, 2000), 347-53; Piotr Guzowski, 'Demograficzne uwarunkowania funkcjonowania rodziny chłopskiej na przełomie średniowiecza i nowożytności', in Cezary Kuklo (ed.), Rodzina, gospodarstwo domowe i pokrewieństwo na ziemiach polskich $w$ perspektywie historycznej - ciagłość czy zmiana (Warsaw, 2012), 79-98.

${ }^{78}$ Andrzej Wyczański, 'O dawnej rodzinie w Polsce i Europie', in Maciej Koźmiński (ed.), Cywilizacja europejska, ii: Eseje i szkice z dziejów cywilizacji i dyplomacji (Warsaw, 2010), 149-64.

${ }^{79}$ Michael Mitterauer and Reinhard Sieder, 'The Developmental Process of Domestic Groups: Problems of Reconstitution and Possibilities of Interpretation', Journal of Family History, 4 (1979), 257-84. 
from leaving their villages was much less restrictive with regard to women, so they had more freedom than men to marry outside their villages.$^{80}$ A parliamentary act of 1511 stated that peasant daughters were to be free to choose their marriage partners. ${ }^{81}$ Close proximity of a town enabled young women first to find employment and then probably also a husband. ${ }^{82}$ However, it appears that most women sought their marriage partners within the boundaries of their parishes or their immediate neighbourhood. ${ }^{83}$ Freedom to choose one's spouse was guarded by the Catholic Church which fought, more or less successfully, against any attempts on the part of the gentry to limit peasants' liberty in this respect. ${ }^{84}$

To sum up, comparison of De Moor and van Zanden's findings concerning the role of the Church in the emergence of the European marriage pattern with the findings of Polish researchers reveals many similarities. Preaching of the Catholic Church on marriage in late medieval Poland did not differ from the Church's preaching on the same subject in late medieval England or the Low Countries. Clergymen used the same, universal, doctrinal programme, and everywhere the same 'West-European' principles of marriage by mutual consent were propagated. In Polish reality, the spreading of the doctrine of consensual marriage strengthening the rights and social position of women was facilitated by factors of demographic nature: parents did not live to see their children marry, and of institutional nature: unlike women's, men's freedom of movement was restricted.

${ }^{80}$ Kazimierz Tymieniecki, Historia chłopów polskich, iii: Geneza zaostrzonego poddaństwa chłopów (Warsaw, 1969), 129-90; Leonid Żytkowicz, 'Przesłanki i rozwój przytwierdzenia do gleby ludności wiejskiej w Polsce - połowa XIV - początek XVI wieku', Przegląd Historyczny, lxxv, 1 (1984), 3-21.

${ }^{81}$ Volumina constitutionum, i, pt. 1, ed. Stanisław Grodziski, Irena Dwornicka, and Wacław Uruszczak (Warsaw, 1996), 247.

82 Jawor, 'Obraz rodziny', 8; Guzowski, 'Demograficzne uwarunkowania', 92-3.

${ }^{83}$ Anna Izydorczyk, 'Rodzina chłopska w Małopolsce w XV i XVI wieku', Andrzej Wyczański (ed.), Społeczeństwo staropolskie. Studia i szkice, vol. 3 (Warsaw, 1983), 9-15.

${ }^{84}$ Zdzisław Kaczmarczyk and Bogusław Leśnodorski, Historia państwa i prawa Polski od potowy XV w. do r. 1795 (Historia państwa i prawa Polski do roku 1795, 2, 2nd edn, Warsaw, 1966), 315; Michał Kopczyński, 'Dwór a rodzina chłopska - przymus i koegzystencja’, in Magdalena Ślusarska (ed.), Dwór - plebania - rodzina chtopska. Szkice z dziejów wsi polskiej XVII i XVIII wieku (Warsaw, 1998), 13-26. 


\section{VI}

\section{TRANSFER OF PROPERTY BETWEEN GENERATIONS}

De Moor and van Zanden argue that another factor contributing to the emergence of European marriage pattern in the north rather than in the south of Europe is differences in the system of inheritance and transference of property between generations and from husband to wife. In Western Europe, the system of inheritance was characterised by the right of women to inherit and to transfer land. A decisive difference between the north and the south concerned, as De Moor and van Zanden explain, the "timing of women's access to their share in the inheritance". ${ }^{85}$ Marriage played a crucial role in it. In South Europe, it was marriage that entitled a daughter to claim her right to her share in the inheritance, which she received in the form of a dowry. In the north, land property was transferred on daughters, as well as on sons, on their parents' death although it was not, of course, completely unusual for living parents in England or the Low Countries to transfer land on daughters or to endow their daughters with some property in the form of a dowry. ${ }^{86}$

De Moor and van Zanden point to regional differences in France as evidence. In the south of France, in the land of written law, the rules of inheritance and transfer of property, equal to all people, regardless of their social standing, were derived from Roman law, unlike in the north, where the system of inheritance was governed by custom. Individuals could decide about their property, how it should be used and transferred. Theoretically, a father could decide not to divide his property into equal parts and thus his children's shares would not be the same because the size of the dowry was in fact negotiated with the family of a future marriage partner. Another difference between northern and southern regions of France concerned the way property was managed within the marriage. The southern model is

${ }^{85}$ De Moor and van Zanden, 'Girl Power', 7-8.

${ }^{86}$ Ibidem, 8. More about inheritance systems see Jack Goody, Joan Thirsk, and E.P. Thompson (eds.), Family and Inheritance: Rural Society in Western Europe 12001800 (Cambridge, 1976); about medieval England, cf. Richard Smith, 'Women's Property Rights under Customary Law: Some Developments in the Thirteenth and Fourteenth Centuries', Transactions of the Royal Historical Society, 5th Ser., 36 (1986), 165-94; about Low Countries, see Martha C. Howell, The Marriage Exchange: Property, Social Place, and Gender in the Cities of the Low Countries, 1300-1550 (Chicago and London, 1998). 
often referred to as 'separatist' because the property that a husband and wife brought into the marriage as a dowry was treated separately; individual property of a wife did not merge with the property of her husband. The northern model is known as 'conjugal' because at marriage the property of a wife and the property of a husband merged to create a conjugal fund. The fund was under the full control of a man, but it did not preclude the wife's right to her share in it. Moreover, the rule was that both spouses were equally entitled to their shares in property accumulated by them during the marriage. ${ }^{87}$ This rule, De Moor and van Zanden argue, was a reason why northern women could be, at least in theory, more motivated to help to increase their conjugal property. Since the wealth of southern women "was more or less fixed, regardless of what economic activities they undertook", they were much less motivated to undertake any economic activity at all. The rule had some implications for the position of widows in the north. Their right to wealth accumulated during the marriage put them in a favourable position in comparison with their southern counterparts. They could invest their wealth in a new business. Moreover, property at their disposal made them more attractive to potential partners, hence they were more likely to remarry. ${ }^{88}$

The north-south divide is even more evident with regard to the transfer of property between generations. In Italy, once a daughter was endowed with a dowry, she lost her right to any further share in her father's property. The Italians called this system fraterna, in France it was called frérèches. The system had its important demographic implications. Parents as well as daughters were interested in arranging the marriage as soon as possible, which resulted in lowering of the age at marriage. ${ }^{89}$ In North-Western Europe, where the inheritance system was often based on primogeniture, but also guaranteed women

87 De Moor and van Zanden, 'Girl Power', 9-11; Emmanuel Le Roy Ladurie, 'Family Structures and Inheritance Customs in Sixteenth-Century France', in Goody, Thirsk, and Thompson (eds.), Family and Inheritance, 37-70.

${ }^{88}$ De Moor and van Zanden, 'Girl Power', 8.

${ }^{89}$ Ibidem, 9. For more on the southern system, see Julius Kirshner and Anthony Molho, 'The Dowry Fund and the Marriage Market in Early Quattrocento Florence', Journal of Modern History, 50 (1978), 403-38; Anthony Molho, 'Deception and Marriage Strategy in Renaissance Florence: The Case of Women's Ages', Renaissance Quarterly, 41 (1988), 193-217; idem, Marriage Alliance in Late Medieval Florence (Harvard Historical Studies, 114, Cambridge, Mass., 1994). 
equal rights to their parents' inheritance, women were not pressurised to marry early. ${ }^{90}$

The assessment by Polish historians of the legal status of women in historic Poland is not clear-cut. In his pioneering work Polskie prawo majątkowe-matżeńskie $w$ wiekach średnich [Polish property and marriage law in the Middle Ages], Alojzy Winiarz wrote:

In medieval Poland a woman was seen as an equal to a man member of the family of birth, and thus her right to a share in family property was seen as equal to that of a man. ... When she married, she was entitled to take the part of family property that was her share and contribute it to her marriage. This part was called a dowry. A daughter who got married before her father's death was not supposed to demand her dowry, as it was her father's decision to give it to her or not. After the father's death, however, the daughter had the right to demand her dowry, being her share in the patrimony, from her male relatives who inherited the father's property. ${ }^{91}$

Maria Koczerska emphasised the importance of legal procedures at work when a gentry woman was given her dowry:

The practice of official renouncement by [a daughter - PG] provided with a dowry of her further claims to her late father's and mother's property, or the practice of giving guarantees, indicate that although the notion of exdotare was understood as exhereditare, daughters were still formally entitled to an equal share in the patrimony, while their dowries were usually smaller than it. ${ }^{92}$

This same author, writing about the inheritance system of Polish gentry, concluded that

the characteristic feature of Polish family at the turn of the Middle Ages ... was the equality among siblings, or to be more accurate, the equality between brothers and sisters. ${ }^{93}$

90 De Moor and van Zanden, 'Girl Power', 9.

${ }^{1}$ Alojzy Winiarz, Polskie prawo majątkowe-matżeńskie $w$ wiekach średnich (Cracow, 1898), 3.

${ }^{92}$ Koczerska, Rodzina szlachecka, 51.

${ }^{93}$ Maria Koczerska, 'Geneza, znaczenie i program dalszych badań nad kobietą i rodziną w średniowieczu i nowożytności’, in Zenon H. Nowak and Andrzej Radzimiński (eds.), Kobieta $i$ rodzina $w$ średniowieczu i na progu czasów nowożytnych (Toruń, 1998), 10. 
In their fundamental work Historia państwa i prawa w Polsce [History of state and law in Poland], in a chapter devoted to the law of the gentry in the early modern era, Kaczmarczyk and Leśnodorski state that

patrimony was inherited by sons as well as daughters, but the sons were entitled to three quarters of the property, whereas all daughters, regardless of their number, were entitled to only one quarter of the patrimony. ${ }^{94}$

In this system, dowry was treated as an integral part of daughters' share in family property.

If their dowries exceeded the value of a quarter of the patrimony, daughters were obliged to give the excess back to their brothers, which was known as comportation of dowries. If the value of the dowry was lower than that of a quarter of the patrimony, the difference was to be compensated..$^{95}$

For a very long time, women were not allowed to be given their dowries in the form of real estate and were provided with movables instead. ${ }^{96}$ To sum up, formal laws and their practical applications with regard to gentry daughters were not uniform. The time when they were given their dowries, their value, and the size of daughters' share in patrimony varied and depended on many external factors, such as regional customs, wealth of the family, number and sex of inheritors. All these circumstances had some impact on decisions to hasten or delay marriage. Although laws and practices described above concerned a relatively small group of the gentry, it is possible that they also had some indirect influence on the inheritance systems of the less privileged, peasants and townspeople.

As Anna Izydorczyk states, "Peasants in Lesser Poland observed the rule that the estate of parents should be divided among all children". ${ }^{97}$ The farm was normally transferred on the eldest son, but his duty was to pay off his siblings. If there was no male heir, the farm could be transferred on daughters, but in practice they either sold the farm or the estate was taken over by the husband of one of them. Widowed mother of the children was entitled to a third of her late husband's

${ }^{94}$ Kaczmarczyk, Leśnodorski, Historia państwa, 293.

95 Ibidem, 295.

${ }^{9}$ Ibidem, 293; Przemysław Dąbkowski, Prawo prywatne polskie, 2 vols. (Lvov, 1910-11), ii, 17-29.

97 Izydorczyk, 'Rodzina chłopska', 26. 
property. The rule was that the main heir did not divide the land so that the widow could be given her share, but established the value of the land and paid it to the widow in cash. The dowry played a less important role in this system. It often took the form of movables or cash endowments. What was of much greater importance was the fact that women were legally entitled to share in their parents' and husbands' real estate, which considerably strengthened the position of peasant daughters, wives and widows. ${ }^{98}$

A similar system of inheritance was used by townspeople following either the Magdeburg (municipal law) or the Culm (Chełmno) law in which men and women had equal rights to patrimony ${ }^{99}$ (although the two legal systems differed in their treatment of family property; the law of Magdeburg assumed division of marital property, whereas the Culm law assumed joined property). Polish historians claim that at marriage townswomen were provided with a dowry and gerade (household goods), but it did not exclude them from among the inheritors of their parents' property. Their dowries were simply deducted from the rest of their inheritance. ${ }^{100}$ However, scholars studying urban systems of inheritance have not answered some other questions that are fundamental from the demographical point of view: When exactly were daughters given (not just promised) their dowries? Was it done at marriage or after their parents' death? What were inheritance rights of unmarried daughters? All these questions

${ }^{98}$ Józef Rafacz, 'Włościańskie prawo spadkowe w Polsce nowożytnej’, in Zwyczaje spadkowe wtościan w Polsce, vol. 5 (Warsaw, 1925), 23; Juliusz Bardach, Historia państwa i prawa Polski do połowy XV wieku (Historia państwa i prawa Polski do roku 1795, i, Warsaw, 1964), 506; Piotr Guzowski, 'System dziedziczenia chłopów polskich w XV i XVI wieku', in Kuklo (ed.), Rodzina, gospodarstwo, 29-35.

${ }_{99}$ Bartłomiej Groicki, Porządek sąów $i$ spraw miejskich prawa magdeburskiego w Koronie Polskiej, ed. Karol Koranyi (Warsaw, 1953), 181; Krystyna Bukowska, Orzecznictwo krakowskich sądów wyższych w sporach o nieruchomości miejskie (XVIXVIII w.) (Warsaw, 1967), 86; Marek Sędek, 'Czy uprawnienia majątkowe kobiet w Starej Warszawie odpowiadały zasadom prawa chełmińskiego', in Aleksander Gieysztor (ed.), Warszawa średniowieczna (Studia Warszawskie, xiii, 1, Warsaw, 1972), 135-47; Andrzej Karpiński, Kobieta $w$ mieście polskim $w$ drugiej połowie XVI i w XVII wieku (Warsaw, 1995), 29-30; Urszula Sowina, 'Wdowy i sieroty w świetle prawa w miastach Korony w późnym średniowieczu i wczesnej nowożytności', in Maria Dąbrowska and Andrzej Klonder (eds.), Od narodzin do wieku dojrzatego. Dzieci i młodzież w Polsce, i: Od średniowiecza do wieku XVIII (Warsaw, 2002), 26.

${ }^{100}$ Karpiński, Kobieta $w$ mieście, 28. 
call for future research in Poland. Examination of early modern legal treaties and interpretations has not been of much help either because they do not contain any suggestions on whether there was any relationship between the inheritance system and people's decisions about when to marry. ${ }^{101}$ Therefore, there are no sufficient grounds for the claim that demographic consequences of the inheritance systems used by the inhabitants of Polish lands were either similar to or different from those experienced by the people in North-Western Europe. On the one hand, daughter's right to inherit real estate, which usually happened after the death of her parents, may have led to delaying marriage. On the other hand, the practice of renouncing further claims to patrimony by women provided with a dowry at marriage may indicate that the inheritance was no incentive to delaying marriage.

\section{VII \\ LABOUR MARKET}

According to Tine De Moor and Jan Luiten van Zanden, labour market was the third most important factor contributing to the emergence of the European marriage pattern, after the teaching of the Catholic Church and the patterns of inheritance. ${ }^{102}$ Changes in its structure were caused by the outbreak of the Black Death and the renewed outbreaks of the disease later in the Middle Ages. One of the consequences was an increase in the demand for female labour. Women in villages as well as in towns became active in sectors of economy previously dominated by men. ${ }^{103}$ Of particular importance in this context was domestic servanthood, especially in towns. In North-Western Europe, unlike in Italy, women entered service more often than men. ${ }^{104}$ Another significant difference between the north and the south lay in the circumstances of entering service. In the north, domestic service was a free career choice made with the aim of saving enough money to be able to establish a family. In the south, women treated domestic service as the least desirable

${ }^{101}$ Małgorzata Delimata, 'Prawo rodzinne w pracach Bartłomieja Groickiego (ok. 1534-1605)', in Karpiński et al. (eds.), Społeczeństwo a rodzina, 21-37.

102 De Moor and van Zanden, 'Girl Power', 11.

${ }_{103}$ Barbara A. Hanawalt, The Ties that Bound: Peasant Families in Medieval England (New York and Oxford, 1986); Goldberg, Women, Work.

${ }^{104}$ De Moor and van Zanden, 'Girl Power', 11-12. 
occupation. ${ }^{105}$ It is also mentioned by De Moor and van Zanden that after the Black Death labourers' wages rose much faster than food prices and that the increase concerned male as well as female workers, who were often paid almost the same as men. The authors pointed out also that young people were given opportunity to become wageearning labourers as early as at the age of 12 to $14 .{ }^{106}$ All these factors led to particular economic and demographic consequences and to some changes in social practices which, in turn, facilitated the emergence of the European marriage pattern. Firstly, young women gained a chance to become independent of their parents without necessarily getting married and they used this opportunity to assume control over their lives. They now had more freedom to select a husband, to delay a decision to marry, or not to marry at all. On the other hand, however, women's greater independence of parental control resulted in them becoming more subject to fluctuations in wage rates and total economic situation. These two factors eventually began to determine women's decisions concerning marriage. According to De Moor and van Zanden, average age at marriage had risen by the end of the sixteenth century as a result of declining economy and growing population. ${ }^{107}$

Marriage based on consensus was characterised by deeper emotional relationship between spouses. Children born in such families enjoyed greater freedom, as their parents were willing to let them live on their own at a relatively early age. Domestic service and apprenticeship became popular lifestyle choices among young people and an important part of people's life cycle, allowing them to acquire professional skills and experience (social capital). From the later Middle Ages onwards, the number of servants steadily increased to reach at least 10 to 15 per cent of England's total population. ${ }^{108}$ At the same time, taken as a percentage, wage earners represented 20 to 50 per

${ }^{105}$ Richard Smith, 'Geographical Diversity in the Resort to Marriage in Late Medieval Europe: Work, Reputation and Unmarried Females in Household Formation Systems of Northern and Southern Europe', in P.J.P. Goldberg (ed.), Women is a Worthy Weight: Women in English Society, c. 1200-1500 (Wolfeboro Falls, N.H., 1992), 45.

${ }^{106}$ De Moor and van Zanden, 'Girl Power', 12-13, 15, 17.

107 Ibidem, 16-17.

${ }^{108}$ Laslett, Familiy Life, 93; Ann Kussmaul, Servants in Husbandry in Early Modern England (Cambridge, 1981), 12-13; Larry R. Poos, A Rural Society after the Black Death: Essex 1350-1525 (Cambridge, 1991), 187; Graham Mayhew, 'Life-Cycle, Service and the Family Unit in Early Modern Rye', Continuity and Change, 5 (1990), 201-3. 
cent of the population in England and about 60 per cent in the Low Countries at the beginning of the early modern period. ${ }^{109}$

While the expansion of labour market at the turn of the Middle Ages was characteristic of North-Western Europe, it was by no means unique to this region. Although the growth of Polish urban centres was not as spectacular as, for instance, in the Low Countries, relatively smaller demand for labour in towns was offset by an increase in demand for labour in the country. The number of towns in the Crown increased from 706 in 1500 to 932 a century later. Town and city dwellers represented about 25 per cent (about 1 million) of the population of Poland, which in 1580 was 3.65 million people. ${ }^{110}$ The majority of Polish towns were relatively small, which was a feature of Central and Eastern European urban development. Only 6 per cent of total population lived in towns with population over 5,000. ${ }^{111}$ Nevertheless, migration patterns show that even those small towns attracted peasant youth and offered them a variety of employment opportunities. It can be seen through marriage strategies of peasant children. For example, citizens of fifteenth-century Lublin, whose population was nearly 5,000, frequently found their marriage partners among peasant men and women working as domestic servants and/ or apprentices in Lublin. Statistics reveal that most of them came from villages within a radius of $20 \mathrm{~km}$ from the city. ${ }^{112}$ In case there was no larger town or city in the area, statistics show that peasants searching for jobs and marriage partners migrated to places even $80 \mathrm{~km}$ away from their villages. ${ }^{113}$ The earliest available quantitative data concerning the number of domestic servants in big cities come from the eighteenth century. They show that servants made up 20 (Warsaw) to 35 per cent (Cracow) of the cities' population. ${ }^{114}$

109 Bas van Bavel, 'Rural Wage Labour in the 16th-Century Low Countries: An Assessment of Importance and Nature of Wage Labour in the Countryside of Holland, Guelders and Flanders', Continuity and Change, 21 (2005), 65; Christopher Dyer, Age of Transition? Economy and Society in England in the Later Middle Ages (Oxford, 2005), 218-20.

110 Maria Bogucka and Henryk Samsonowicz, Dzieje miast i mieszczaństwa w Polsce przedrozbiorowej (Wrocław, 1986), 119, 332. Ryszard Szczygieł, Lokacje miast $w$ Polsce $w$ XVI wieku (Lublin, 1989), 99.

111 Kuklo, Demografia, 234.

112 Jawor, 'Obraz rodziny chłopskiej', 8.

113 Guzowski, 'Demograficzne uwarunkowania', 92-3.

114 Kuklo, Demografia, 367. 
One of the chief attractions of towns was that they offered better living standards. Research into the standards of living in early modern Polish towns commenced recently by Mikołaj Malinowski reveals that in the sixteenth century the quality of life in the largest urban centres increased (Cracow, Warsaw) or at least remained at the previous good level (Gdańsk). The economic crisis in the seventeenth century did not cause any dramatic deterioration. In the second half of the eighteenth century the labourers in Warsaw, Poznań and Lublin experienced further significant improvement in their living standards. ${ }^{115}$

Another factor which ought to be mentioned in the context of the rise of labour market in Poland is a rapid development of manorial economy at the beginning of the early modern period. Manorial economy in Poland is popularly associated with the exploitation of peasants working for free on their lords' lands. Although the use of forced labour was gradually increasing over the decades, it was by no means the only form of labour arrangement. In the second half of the sixteenth and in the first half of the seventeenth century, only 13 to 36 per cent of royal manors in Lesser Poland did not hire labourers and relied on forced labour only. Similarly, as many as 76 per cent of manors run by noblemen hired extra hands and so did 89 per cent of manors owned by the clergy. ${ }^{116}$

Irrespective of the above facts, a group of hired labourers in the Polish country was relatively smaller than in the Netherlands or elsewhere in Western Europe. The majority of peasant families derived their income and sustenance from their own farms, but these were not economically isolated, self-sufficient farms as defined by Alexander V. Chayanov. Polish peasants engaged, especially since the sixteenth century, into market production of foodstuffs and into proto-industrial activity. ${ }^{117}$ Throughout the late Middle Ages and at the beginning of the early modern period, the Crown of the Kingdom

${ }^{115}$ Mikołaj Malinowski, Real Wages in the Kingdom of Poland in a Global Perspective, 1500-1795: Skill-Premium and the Little Divergence (paper presented at the workshop: 'The Global and Long-term Development of Real Wages: Methods, Problems and Possibilities', in IIHS, Amsterdam, Nov. 2, 2012).

116 Kamler, Chtopi, 39.

117 Ad Knotter, 'Problems of the "Family Economy": Peasant Economy, Domestic Production and Labour Markets in Pre-Industrial Europe', in Marteen Prak (ed.), Early Modern Capitalism: Economic and Social Change in Europe 1400-1800 (London and New York, 2005), 140. 
of Poland was characterised by abundant land resources and continuous shortage of labour. In the second half of the sixteenth century population density in Poland was lower than in Western Europe, with an average rate of 20 people per 1 sq. $\mathrm{km}$ in Poland ${ }^{118}$ (30 people/ sq. $\mathrm{km}$ in England, 40/sq. $\mathrm{km}$ in the Netherlands). ${ }^{119}$ On the other hand, average acreage of peasant farms in Poland was significantly bigger than in England, France, or the Netherlands. A typical latesixteenth-century peasant farm in the south of the Crown (Lesser Poland, Red Ruthenia) occupied half a mansus of arable land (over 8 ha $=$ ca. 20 acres); farms in relatively less wealthy Masovia region were of similar size, whereas in Greater Poland and Royal Prussia average acreage of peasants' farms was much, usually twice, larger. ${ }^{120}$ Moreover, acquisition of land was not difficult and land prices were relatively low. ${ }^{121}$ As a result, coming-of-age peasant sons and young manorial servants were not doomed to joining the group of landless peasants working as seasonal workers, but they could relatively easily set up their own farms. It is estimated that both in Western Europe ${ }^{122}$

118 Irena Gieysztorowa, 'Ludność', in Antoni Mączak (ed.), Encyklopedia historii gospodarczej Polski do 1945 roku, 2 vols. (Warsaw, 1981), i, 431.

119 Etienne Helin and Ad van der Woude, 'Les Pays-Bas', in Jean-Pierre Bardet and Jacques Dupaquier (eds.), Histoire des populations de l'Europe, i: Des origines aux prémices de la révolution démographique (Paris, 1998), 429.

120 Andrzej Wyczański, Studia nad gospodarka starostwa korczyńskiego 1500-1660 (Warsaw, 1964), 105; Jadwiga Muszyńska, Gospodarstwo chtopskie w starostwie sandomierskim 1510-1663 (Kielce, 1991), Tables 9-12; Józef Półćwiartek, Położenie ludności wiejskiej starostwa leżajskiego w XVI-XVIII wieku (Warsaw and Cracow, 1972), 132; Leonid Żytkowicz, Studia nad gospodarstwem wiejskim $w$ dobrach kościelnych w XVI w. (Warsaw, 1962), Table 1; Andrzej Nowak, Początki kryzysu sit wytwórczych na wsi wielkopolskiej w końcu XVI i pierwszej połowie XVII wieku (na przykładzie województwa kaliskiego) (Warsaw and Poznań, 1975), Tables 20-2; Witold Jakóbczyk, 'Uwarstwienie ludności wiejskiej w królewszczyznach zachodnich województw Korony w II poł. XVI w.', Roczniki Dziejów Społecznych i Gospodarczych, v (1936), 58; Antoni Mączak, Gospodarstwo chłopskie na Żuławach Malborskich $w$ poczatkach XVII $w$. (Warsaw, 1962), 48, 275.

121 Piotr Guzowski, 'The Peasant Land Market in Late Medieval and Early Modern Poland, Fifteenth and Sixteenth Centuries', in Gerard Béaur et al. (eds.), Property Rights, Land Markets and Economic Growth in the European Countryside (13th-20th Centuries) (Turnhout, 2013), 219-37.

122 Guy Bois, The Crisis of Feudalism: Economy and Society in Eastern Normandy c. 1300-1550 (Cambridge, 1984), 149-55; Emmanuel Le Roy Ladurie, The French Peasantry 1450-1660, trans. Alan Sheridan (Aldershot, 1986), 57; Harry Kitsikopoulos estimated that 7 hectares was an acreage that guaranteed self-sufficiency 
and in Poland, ${ }^{123} 4-5$ ha was an acreage that guaranteed self-sufficiency of peasant farms. In the second half of the sixteenth century, 90 per cent of peasant farms in Korczyn Starosty ${ }^{124}$ and 92 per cent of farms in Sandomierz Starosty (both in Lesser Poland) were of this or bigger size. The situation in other regions was alike. In the late sixteenth century, in the wealthy Greater Poland, the share of peasants whose farms were smaller than 4-5 ha was only about 2 per cent; in less wealthy Kuyavia and in central Poland this figure was 2.1 to 7.1 per cent. ${ }^{125}$ Finally, the group of villagers (male peasants) who did not possess hereditary farms at all was also relatively insignificant, reaching 10 to 15 per cent of rural heads of family in Lesser Poland. ${ }^{126}$ Hence, the numerical strength and economic role of the group from which hired labourers originated was rather insignificant.

The growth in the commercialisation of Polish economy in the sixteenth century was much less significant than that observable in the most developed West- and North-European countries. The natural conditions and the social system did not favour the expansion of agrarian capitalism, either. Also, the degree of urbanisation in Poland was incomparably lower than in the Netherlands and in England.

Labour market in agriculture-oriented Kingdom of Poland, much smaller than in Western and Northern Europe, offered more job opportunities to men than to women. At the end of the eighteenth century (for which better demographic data are available), the sex ratio of males to females among rural servants was 150-151 to $100,{ }^{127}$ 98 to 100 in small towns, and 90 to 100 in the largest city - i.e. Warsaw, with its 100,000 inhabitants. ${ }^{128}$ Among urban domestic

of peasant farms in England, see idem, 'The Impact of the Black Death on Peasant Economy in England 1350-1500', Journal of Peasant Studies, 29 (2002), 74.

${ }^{123}$ Piotr Guzowski, 'Wyznaczniki biedy w społeczności chłopskiej w początkach epoki nowożytnej', in Grzegorz Miernik (ed.), Bieda w Polsce (Kielce, 2012), 35-47.

${ }^{124}$ Andrzej Wyczański, Uwarstwienie społeczne w Polsce XVI wieku. Studia, (Wrocław, 1977), 93.

${ }^{125}$ Stefan Cackowski, Gospodarstwo wiejskie w dobrach biskupstwa $i$ kapituty chetmińskiej w XVII-XVIII wieku, i: Gospodarstwo chtopskie (Toruń, 1961), 100; Żytkowicz, Studia nad gospodarstwem, Table 1.

${ }^{126}$ Wyczański, Uwarstwienie społeczne, 91.

${ }^{127}$ Kopczyński, Studia nad rodzina chtopska, 127; Szołtysek, 'Life-Cycle Service', 66.

${ }^{128}$ Cezary Kuklo, 'Społeczno-demograficzny cykl życia człowieka w mieście staropolskim u schyłku XVIII wieku', Roczniki Dziejów Spotecznych i Gospodarczych, lxii (2002), 102. 
servants in the 15-24 age group men constituted as much as 60 to 75 per cent. ${ }^{129}$ The demand for female labour was much lesser. Girls left their family homes at about the same age as boys, but they tended to quit service earlier and to marry younger than boys. In the case of women, the period of service preceded marriage less frequently than in the case of men. ${ }^{130}$ One interesting phenomenon was noticed by Michał Kopczyński who studied peasant families in historic Poland. He divided peasant servants into two groups: (i) peasant servants employed by other peasants, and (ii) peasant servants employed by the gentry in their manors. Average age of members of the first group in eighteenth-century Kuyavia was 23.7 for men and 20.7 for women, which was lower than the average age at marriage. In contrast, the average age in the second group, 31.2 for men and 28 for women, was higher than the average age at marriage. Among servants working in peasant households, 12 per cent were either married or widowed, whereas the figure for servants employed by the gentry was 28 per cent. ${ }^{131}$ This may be indicative of greater stability of employment at manorial farms. Married servants may also have been preferred by their gentry employers because they were more predictable. Another explanation for demographic differences between servants from group (i) and (ii) given by Michał Kopczyński is that

manorial servants more often than servants employed at peasant farms came from among the poorer peasants. Since they did not have a chance to acquire their own farms, service in the manor house or at the manorial farm provided an opportunity of stable employment. ${ }^{132}$

Members of this group were more likely than other peasants to delay marriage, just like their more numerous counterparts in Western and Northern Europe. This is why, although the Crown had a different economic system than the Netherlands or England, it also provides arguments to support Tine De Moor and Jan Luiten van Zanden's theory that the 'European' marriage pattern primarily characterised hired labourers. In Polish economic reality, this group was much smaller than in the West, but it did exist. It seems that further

\footnotetext{
${ }^{129}$ Idem, Demografia, 367.

130 Szołtysek, 'Life-Cycle Service', 70.

131 Kopczyński, Studia nad rodzina chtopska, 122.

132 Ibidem, 125.
} 
studies into the links between demographic situation, economic and occupational status, and the standards of living in Poland will most probably provide more arguments in support of the De Moor and van Zanden theory.

Although some factors contributing to the emergence of the European marriage pattern operated also in Poland - marriage based on consent and inheritance system, not always so different from that in the Northern and Western Europe - the age of Polish women at first marriage was lower than in the Netherlands and in England. It appears that the reasons for delaying marriage (one of the defining features of the European marriage pattern) were related to the characteristics of labour market and overall economic development, which in Poland were different from the capitalist model typical of Northern and Western Europe. On the other hand, it is worth remembering that in the multiethnic and multicultural Commonwealth (as well as in the Polish Crown itself), there were pronounced regional differences. Mikołaj Szołtysek has recently presented demographic descriptions of Silesia, the major regions of the Crown inhabited by Catholics, Red Ruthenia with its diverse population dominated by Orthodox and Greek-Catholic Ruthenians, and parts of northern voivodeships of the Grand Duchy of Lithuania (most of them in today's Belarus) inhabited also by Orthodox and Greek Catholic Ruthenians. ${ }^{133}$ Szoltysek's study reveals that the demography of pre-industrial family was influenced by more factors than the three proposed by De Moor and van Zanden. Bearing this in mind, we will now supplement our reflection upon the Dutch scholars' work by presenting the theory of Michael Mitterauer.

\section{VIII}

\section{HIDE SYSTEM}

According to Michael Mitterauer, the major factors influencing the demographic system of European population, such as the characteristic way of household formation, dominance of nuclear families, advanced age at marriage, high percentage of unmarried people, the hiring of domestic servants as additional labour force in a household, and the institution of retirement as a way of providing care to elderly

133 Szołtysek, 'Life-Cycle Service', 58, 60. 
parents, all have early mediaeval, feudal origins. Mitterauer's emphasis on these early roots distinguishes his theory from the theory of Tine De Moor and Jan Luiten van Zanden who saw the origins of all these phenomena in late medieval, capitalist environment.

The most important source in Mitterauer's study of family demography in the early Middle Ages is a Carolingian polyptych, a register of people and property in one ninth-century abbey. ${ }^{134}$ The most common system of organisation of large land estates was the so-called le domaine bipartite (bipartite domainial structure). Mitterauer shows that the Carolingian hide system (Huffenverfassung) spread also to Central Europe where its expansion was connected with the German colonisation and dissemination of the 'German law'. We can add that in the late Middle Ages the hide system embraced also large parts of Poland, and at the beginning of the early modern era it reached the Grand Duchy of Lithuania. Mitterauer claims that the hide system is a good explanation for the prevalence of simple households based on nuclear families. The hide system favoured unigeniture because it prevented fragmentation of peasant farms, which suited the peasant and the lord alike. ${ }^{135}$ Although in Poland inheritance customs entailed equal division of patrimony among all children, regardless of sex, in practice farms were handed down to one heir (or sold), who paid off his siblings. ${ }^{136}$

This way of handing down peasant farms contributed to the formation of the institution of peasant retirement in Poland, similar to that known in Western Europe. According to Michael Mitterauer, an elderly peasant in Western Europe who turned over the farm to his heir or sold it to a new owner was entitled to live in and of the farm until his death, although he no longer was the head of the household. This role was taken over by the new owner, who also took over all feudal obligations. ${ }^{137}$ This is exactly what Polish peasants practiced when they adopted the institutions of wymowa and wycug (retirement contract). ${ }^{138}$ Village court rolls, being primarily registers of peasants'

${ }^{134}$ Mitterauer, Why Europe?, 58-9; Carl I. Hammer, 'Family and Familia in EarlyMedieval Bavaria', in Wall, Robin, and Laslett (eds.), Family Forms, 217-48.

135 Mitterauer, Why Europe?, 63.

136 See footnote 99.

${ }^{137}$ Mitterauer, Why Europe?, 65.

${ }^{138}$ Michał Kopczyński, 'Starość nie radość? Ludzie starzy na wsi kujawskiej u schyłku XVIII stulecia', Zapiski Historyczne, 61 (1996), 45-64; idem, Studia nad rodzina, 147-66. 
land transactions, contain evidence for the existence of these practices from at least the sixteenth century onwards. ${ }^{139}$ Hence, Mitterauer's explanation of the dominance of simple households in Western and Northern Europe would apply to the Crown as well.

Application of Mitterauer's theory to Polish reality has some limitations. One of them is that there are substantial exceptions to it. For example, areas in the Polish Crown and the Grand Duchy of Lithuania inhabited by the Ruthenians were characterised by a large proportion of complex households in spite of the existence of the hide system there. It must be remembered though that in the beginning the 'German law' was supposed to be followed by Catholics only. The rule was to ensure that newly founded villages were settled by people from the Crown or even from Western Europe rather than by the Ruthenians from neighbouring villages. ${ }^{140}$ During the sixteenth century, villages under Ruthenian and Valachian law (in the Subcarpathian region) became similar to those that followed the 'German law', but similarities concerned the organisation of village self-government, not the organisation of households. Theoretically, a factor that should have a much greater influence on the latter was the process of commercialisation of Polish economy taking place at the beginning of the early modern era. In practice, however, the economic and social impact of commercialisation on the lands which were not involved in the Baltic trade was minimal. ${ }^{141}$ Red Ruthenia, but also Minsk and Nowogródek voivodeships in the Grand Duchy of Lithuania, researched recently by Mikołaj Szołtysek, are characterised not only by a different ecosystem, but also by a significantly lower level of urbanisation, smaller population density ( 8 persons/sq. $\mathrm{km}$ at the

${ }^{139}$ Andrzej Wyczański, 'Opieka nad ludźmi starymi na wsi polskiej w XVI w.', in Maurice Aymard et al. (eds.), Biedni $i$ bogaci. Studia $z$ dziejów spoteczeństwa $i$ kultury ofiarowane Bronistawowi Geremkowi w sześćdziesiąta rocznicę urodzin (Warsaw, 1992), 65-70; Piotr Guzowski, 'Starość w cyklu życia kmieci polskich przełomu średniowiecza i czasów nowożytnych', Kwartalnik Historii Kultury Materialnej, 58 (2010), 101-18.

${ }^{140}$ Andrzej Janeczek, 'Exceptis schismaticis. Upośledzenie Rusinów w przywilejach prawa niemieckiego Władysława Jagiełły', Przegląd Historyczny, lxxv, 3 (1984), 528-34; Małgorzata Kołacz-Chmiel, Spoteczności chtopskie ziemi chetmskiej w późnym średniowieczu (Lublin, 2009), 17-37.

${ }^{141}$ Piotr Guzowski, 'Upieniężnienie gospodarki w Polsce na przełomie średniowiecza i czasów wczesnonowożytnych', in Borys Paszkiewicz (ed.), Upieniężnienie. Kiedy moneta staje się pieniądzem (Nowa Sól, 2011), 105-19. 
end of the 18th century), lesser development of local markets than in the Crown, which inevitably influenced the demographic structure of these areas. ${ }^{142}$

Michael Mitterauer's study of the family and economy in an estate belonging to a Carolingian abbey shows more features of the European marriage pattern in the period as early as the ninth century. He claims that feudal lords did not allow peasant sons to marry until they were old enough to take over their father's farm or any other available. A high number of so-called baccularii and baccularie, i.e. young, unmarried people over the age of 15 (a group much bigger than the group of children) is, according to Mitterauer, indicative of the importance of service in the life-cycle of peasants and proves that the age at marriage must have been relatively advanced. Moreover, Carolingian sources provide evidence for the existence of a large group of unmarried servants working either in their lords' manors or on the farms of other peasants. The abovementioned polyptych made relatively few mentions of widows, which, as Mitterauer believes, suggests that there was a great pressure on widows to remarry. ${ }^{143}$

According to Mitterauer, all these characteristics of early medieval population prove that Hajnal's European marriage pattern had existed long before its supposed emergence. There is, however, a weakness to Mitterauer's engrossing argumentation. It must be remembered that Carolingian polyptychs did not specify the ages of people whose names they recorded. Consequently, Mitterauer's presumptions about the age at which these people married cannot be verified. Hajnal's theory is based on early modern statistical data whose early medieval equivalents simply do not exist. Even if we recognise the validity of the argument that Carolingian male peasants married at an advanced age as a result of their lords' policy of not allowing peasant sons to marry until they were mature enough to take over their fathers' mansi, it did not automatically mean that Carolingian women also delayed marriage. Late medieval English manorial court rolls, examined in search of evidence for the existence of Hajnal's model, do not provide data about women's age at marriage. They contain only information about special fees paid by marrying women to their lords, but on

${ }^{142}$ Andrzej Wyczański and Leszek Jezierski (eds.), Historia Polski w liczbach, i: Państwo i spoteczeństwo (Warsaw, 2003), 22, 53.

${ }^{143}$ Mitterauer, Why Europe?, 63. 
this basis it is not possible to detect any tendency to either hasten or delay marriage.

Manorial court rolls were used as a source material for demographic studies by Zvi Razi in his excellent, though critically received, ${ }^{144}$ book about English family before and shortly after the Black Death. The results of his analysis of the source, however, do not support the argument that after the Black Death people married later. ${ }^{145}$ Mitterauer's other arguments, those with respect to the high percentage of single people, the existence of life-cycle service, and the institution of retirement, appear convincing, but they still raise a question of whether the data from polyptych describing the inhabitants of large abbey estates were representative of total rural population in Carolingian times.

Full development of all the features of the European marriage pattern in Poland, especially the advanced age at marriage, was hindered by Poland's economic backwardness and institutional obstacles to the expansion of agrarian capitalism, or capitalism as such. As a result, the group of hired labourers in the early modern period was smaller in Poland than in Western and Northern Europe. Therefore, although Hajnal's line was delineated by its author intuitively rather than on the basis of any thorough research, it can be said that, as far as the age at marriage in the Polish-Lithuanian Commonwealth and in Silesia is concerned, Hajnal's intuition did not much fail him. With regard to how far to the East stretched the area where simple households dominated, Hajnal's line requires some modifications and it appears that this revision should differ from that suggested by Karl Kasser. ${ }^{146}$

${ }^{144}$ Larry R. Poos and Richard M. Smith, 'Legal Windows onto Historical Populations? Recent Research on Demography and the Manor Court in Medieval England', Law and History Review, 2 (1984), 130-7; Zvi Razi, 'The Use of Manorial Court Rolls in Demographic Analysis: A reconsideration', Law and History Review, iii, 1 (1985), 191-200; Larry R. Poos, Richard M. Smith, and Zvi Razi, 'The Population History of Medieval English Village: A Debate on the Use of Manor Court Records', in Zvi Razi and Richard Smith (eds.), Medieval Society and the Manor Court (Oxford, 1996), 298-355.

${ }_{145}$ Zvi Razi, Life, Marriage and Death in a Medieval Parish: Economy, Society and Demography in Halesowen 1270-1400 (Cambridge, 1980), 50-63, 135-7.

${ }^{146}$ Karl Kasser, Macht und Erbe. Männerschaft, Besitz und Familie im östlichen Europa (1500-1900) (Vienna, 2000), 75, where historical and cultural boundary between Western and Eastern Europe (also in demographic terms) was drawn in such a way that Cracow and Lesser Poland were classified as Eastern Europe, whereas the majority of Belarussian lands as Western Europe. 
Different origins of the two elements identified by Hajnal as constitutive of the European demographic system (simple households connected with feudalism and advanced age at marriage connected with capitalism) make it impossible to draw only one line demarcating territories were they did or did not exist. Moreover, Hajnal's line does not take into account significant regional differences between various parts of Ruthenian lands in the Crown and in the Grand Duchy of Lithuania. Examination of the reasons for this regional diversity can contribute to increasing interpretation possibilities in the study of the origins of the European marriage pattern.

The pioneering studies of Mikołaj Szołtysek should become an inspiration for more research in this field, especially in the demography of Ruthenian population inhabiting the territories of 'strongly' westernised Red Ruthenia (incorporated into the Polish Crown in mid-14th century) and Grand Duchy of Lithuania, somewhat backward in its civilisational development, for a change. It is also essential that Polish scholars, following the example set by Michał Kopczyński and Mikołaj Szołtysek, start using the tools of statistical analysis (e.g. standard deviation) to show the variability of their sample data, which will make it possible to compare their findings with the work of their West-European colleagues. The achievements of Tine De Moor and Jan Luiten van Zanden, and Michael Mitterauer in explaining demographic phenomena prove the importance of scholarly cooperation between historical demographers and economic, legal and cultural historians. The need for taking a broad perspective in studying the problem of the age at marriage in historic Poland has been recently emphasised by Cezary Kuklo, who observes that

Explaining a noticeable variety in the age at marriage in various parts of early modern Poland is not an easy task. ... It certainly was an outcome of several factors belonging to the local cultural-economic context, such as the control over marriage exercised by the Church, land lords, and rural or urban community; interests of the families of the newlywed (e.g. postponing the apportioning of land or the transference of a farm or a workshop); finances (the possibility of acquiring resources to start one's own household or the possibility of learning a specific trade before entering marriage); biological condition of the population; previous marital status of prospective spouses, their place of living and socio-occupational status. ${ }^{147}$

${ }^{147}$ Kuklo, Demografia, 281. 
It seems therefore that a demographic analysis undertaken in the future by Polish historians will require deeper verification of economic foundations and cultural context in which Polish family functioned. There is also an urgent need for a thorough study of the inheritance systems of various social groups, and creating more precise terminology to be used to describe economic status of the group under study. ${ }^{148}$

proofreading Tristan Korecki

${ }^{148}$ It is more precise and convenient to use the classification based on peasants' property rights and size of holding (proposed by economic historians, e.g. Andrzej Wyczański) than the less accurate terms kmiecie and pótkmiecie, whose meaning varied from region to region across the vast territory of the Commonwealth. 